\title{
Teachers' Perception and Readiness Towards Adaptive Learning in the COVID-19 Pandemic: Thematical Content Analysis Study
}

\author{
Zulmi Ramdani', Maulia Depriya Kembara ${ }^{2}$, Leli Alhapip3, Andi Amri4, Jaka \\ Warsihna ${ }^{5}$, Zulfikri Anas ${ }^{6}$
}

DOI: 10.35445/alishlah.v13i2.915

\begin{abstract}
Article Info
Abstract

Keywords:

Teacher's perception;

Teacher's readiness;

Adaptive learning;

COVID-19;

Thematical content analysis

Technological advances and life dynamics that are changing so fast and so volatile become challenges for teachers to implement their best learning model at every level of education. The study aims to explore the perception and readiness of teachers in conducting adaptive learning in pandemic times. A qualitative research method with thematic content analysis models was used to answer these objectives. A total of 327 respondents who worked as teachers were involved in filling out online questionnaires, and the selection of respondents was carried out with purposive sampling techniques. The results show a diverse perception of respondents regarding changes that occurred in the learning process, and the perception of those changes must be faced with readiness and adaptive. Teachers' readiness could be seen from their strategies that were quite effective in dealing with existing changes. These results also emphasize that respondents realized that face-to-face learning was still considered adaptive learning for them to deliver the material. Meanwhile, teachers felt that an adaptive learning guide was needed to guide the learning process when the change occurred. This study provides a clear picture of the learning concepts needed now and is an early indicator informing adaptive learning guidebooks.
\end{abstract}

Kata kunci:

Persepsiguru;

Kesiapan guru;

Pembelajaran adaptif; COVID-19;

Analisis konten tematik

\begin{abstract}
Abstrak
Kemajuan teknologi dan dinamika kehidupan yang berubah begitu cepat dan sangat fluktuatif menjadi salah satu tantangan tersendiri bagi guru untuk dapat mengimplementasikan model pembelajaran terbaik mereka di setiap jenjang pendidikan. Studi ini bertujuan untuk mengeksplorasi persepsi dan kesiapan guru dalam melakukan pembelajaran adaptif di masa pandemi. Metode penelitian kualitatif dengan model analisis konten tematik digunakan untuk menjawab tujuan tersebut. Sebanyak 327 responden yang berprofesi
\end{abstract}

\footnotetext{
${ }^{1}$ UIN Sunan Gunung Djati Bandung, Bandung, Indonesia Email: zulmiramdani@uinsgd.ac.id

2 Universitas Pendidikan Indonesia, Bandung, Indonesia

Email:maulia@upi.edu

3 Pusat Kurikulum dan Perbukuan, Kemendikbud Ristek, Jakarta, Indonesia

Email: lelialhapip79@gmail.com

4 Universitas Pancasila, Jakarta, Indonesia

Email: andiamri43@gmail.com

5 Universitas Terbuka, Jakarta, Indonesia

Email: jaka.warsihna@gmail.com

${ }^{6}$ Pusat Kurikulum dan Perbukuan, Kemendikbud Ristek, Jakarta, Indonesia

Email: fikrieanaso1@gmail.com
} 
sebagai guru terlibat dalam pengisian kuesioner online dan pemilihan responden tersebut dilakukan dengan teknik purposive sampling. Hasil penelitian menunjukkan bahwa muncul persepsi yang beragam pada responden terkait perubahan yang terjadi dalam proses pembelajaran dan persepsi akan perubahan itu harus dihadapi dengan siap dan adaptif. Kesiapan guru bisa dilihat dari strategi mereka yang cukup efektif dalam menghadapi perubahan yang ada. Hasil ini juga menekankan bahwa responden menyadari bahwa pembelajaran berbasis tatap muka masih dianggap sebagai pembelajaran adaptif bagi mereka untuk menyampaikan materi. Sementara itu, guru merasa bahwa diperlukan sebuah panduan pembelajaran adaptif yang bisa mereka gunakan sekaligus memandu proses pembelajaran ketika perubahan itu terjadi. Studi ini memberikan gambaran yang jelas tentang konsep pembelajaran yang dibutuhkan sekarang sekaligus menjadi indikator awal dalam pembentukan buku panduan pembelajaran adaptif.

\section{INTRODUCTION}

The covid-19 pandemic has become a great history in the lives of humankind today. Almost all aspects of life are negatively affected by the changes that occur due to the pandemic (Kanya et al., 2021; Marliani et al., 2020; Prakoso et al., 2021; Ramdani et al., 2021; Tahrir et al., 2021). Education is one of the crucial aspects that also concerns many people because the impact of the pandemic on the learning system becomes not optimal and causes the psychological development of individuals involved in it to be disrupted (Kanya et al., 2021; Prakoso et al., 2021).

Some facts show that in the context of education itself, many problems arise due to this pandemic. They are starting from learning schemes that turn online because they do not allow faceto-face, the unoptimal use of media and learning instruments because the use of networks and technology limits it, until the changes in psychological dynamics and other unpreparedness arising due to changes in learning that occur (Fauzi \& Sastra Khusuma, 2020; Kanya et al., 2021; Prakoso et al., 2021; Restauri \& Sheridan, 2020; Zvolensky et al., 2020). These matters are certainly a small part of the impacts caused by changes due to the COVID-19 pandemic.

It has been almost two years since the pandemic occurred in 2019; during that time, many parties are trying to develop an effective learning model used in these conditions. Mouratidis dan Papagiannakis (2021) and Yuan et al. (2021) explain that distance learning with learning schemes integrated with traditional media and gamification is very effectively used in these situations. Other studies had shown that effective learning during pandemics could only be achieved when classroom activities can virtually be built through collaboration between students and their parents with the control and guidelines of their teachers (Aldridge \& McQuagge, 2021; Whillans et al., 2021). Meanwhile, in Indonesia itself, many studies develop learning models by focusing on creative media aligned with existing materials (Fitriani, 2020; Mansyur, 2020). Then other studies focus on schools, teachers, and parents' roles in providing easy and optimal learning (Fitrah \& Ruslan, 2020; Kanya et al., 2021; Sudrajat, 2020).

The effective learning that the researchers describe above is part of adaptive learning models. There are already many experts who propose the definition of adaptive learning. Sulasmono and Dwikurnaningsih (2012) explain that adaptive learning is associated with creative, active, and reflective learning models. Thus, it is known as the adaptive, creative, active, and reflective learning model (PAKAR). That is a learning model that integrates an understanding of student learning modalities with learning techniques that activate students, develop students' social skills, and reflect on their learning experiences. Various learning strategies are used in synergy to achieve these goals, namely adaptive, cooperative, active, and reflective learning.

The adaptive learning models described earlier certainly are based on the teacher's ability as a design-maker and implementer of learning. Teachers who are creative and able to develop existing limitations are predicted to implement learning more optimally. However, not all teachers in the 
field can create such an ideal situation. One of them is that there has been no positive perception and attitude, and the teacher's readiness is related to adaptive learning. The absence of synchronization between these things is one of the causes of optimal learning in these pandemic times.

Theoretically, a teacher's perception is a view or what the teacher thinks of an object. Individual perception must be different, which will affect other aspects, including the behaviour they take (Ramdani et al., 2021; Tahrir et al., 2021). Meanwhile, a good perception of pandemic changes will also relate to their readiness personally. This readiness includes aspects of the soul, physical, mental, and other abilities in facing the existing changes (Kanya et al., 2021). The perception and readiness of teachers will be an essential part that must be identified when this pandemic occurs. In this research, as far as the researchers' observations, there is still a lack of studies that focus on aspects of teachers' perception and readiness towards learning to be one of the crucial things that the researchers want to try to get in this study.

\section{METHODS}

The study was conducted using a descriptive qualitative approach where the researchers used a series of open-ended questions to find the exploratory meaning of the topic being studied (Amri et al., 2021). This qualitative research was then focused on answering several important points related. They were; (1) teachers' perception during pandemic learning (example of the indicators; feelings experienced during pandemics, difficulties faced, and strategies used), and (2) teachers' readiness in implementing adaptive learning (the example of the indicators: what is felt, what is done, what is expected and what is planned).

The researchers broke them down into some open-ended questions to get a comprehensive picture of these essential points. Theoretical concepts developed by (Reed et al., 2006; Vandewaetere et al., 2011) in the process of adaptive learning were used as the researchers' basic grand theory for exploration. The examples of questions used in this study include; (1) Tell us about the experiences and strategies that teachers have in facing the learning changes during pandemics? (2) What is the most effective learning process used for learning? (3) What things are used as references by teachers in implementing the curriculum to be effective? In addition, the researchers also asked several selected questions (yes or no) related to the topic that had been determined.

The subjects involved in this study were teachers at the elementary school, junior high school, and high school levels in various regions in Indonesia. Selection of the subjects used purposive sampling techniques, i.e., choosing subjects according to predetermined characteristics (Ramdani, 2017; Warsihna \& Ramdani, 2020). All of the question instruments created in the study were provided online through a Google form link distributed for a month (early June to early July 2021). In addition, the subjects also filled out informed consent that expressed their willingness to engage in research. Data analysis in this study used thematic content analysis that was thorough and specific to qualitative processing results. This analysis was used by gradually identifying each answer submitted by the respondents. The answers that felt most appropriate were then objectified and mapped into a categorical description (see figure 1 for more details).

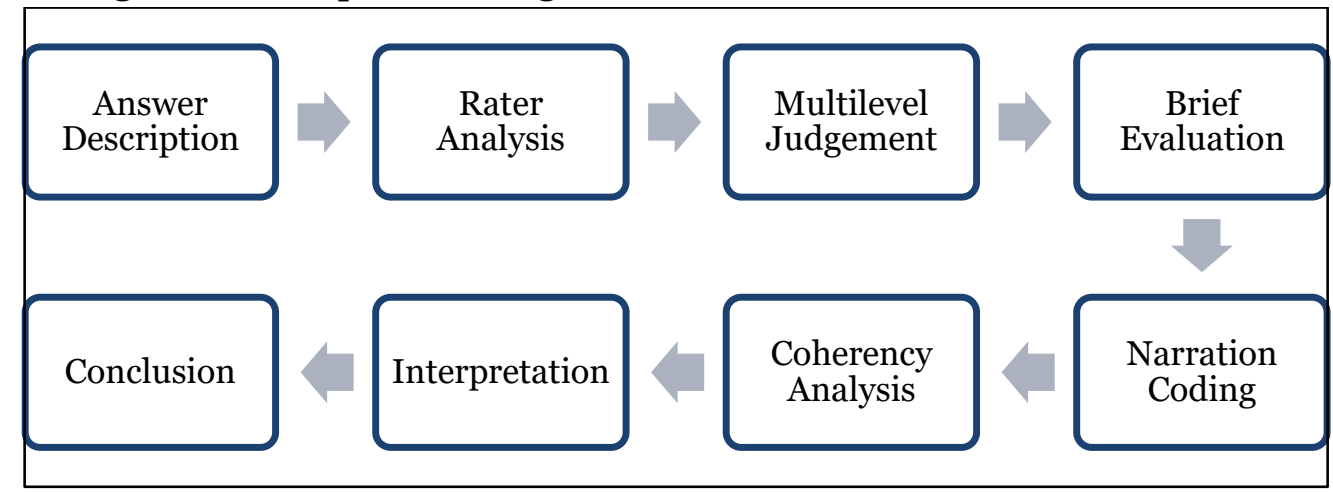

Figure 1. Thematic Content Analysis Flow (Ramdani et al., 2019; Tae et al., 2019) 
Thematic content analysis began with moving the subjects' answers into a worksheet ready to be analyzed (answer description). The answers had been then shared with several raters/assessors, including the research team, to be seen and identified according to the topic raised (rater analysis). After that, each rater was tasked to evaluate the subjects' answers by recording keywords and categorization (multilevel judgment). The analysis results were then discussed briefly to equalize perceptions and results obtained (brief evaluation). Evaluation results were agreed upon and categorized back on relevant topics (narration coding). Then, all teams analyzed whether the results are appropriate or not (coherency analysis). When it is completed, it will be interpreted (interpretation), and the relevant points will be concluded (conclusion).

\section{FINDINGS AND DISCUSSION}

The study involved 350 teachers as respondents from various regions in Indonesia. However, a total of 23 respondents did not fill in the data completely, so that the researchers considered it as outlier data. Thus, 327 respondents were found to be able to be involved in this study. The 327 respondents consisted of $76.8 \%$ women, and the remaining $23.2 \%$ were men. The level of education they taught was categorized into $43.2 \%$ of teachers at elementary school or its equivalent, $35.7 \%$ of teachers at junior high school or its equivalent, while $11.1 \%$ were teachers at high school or its equivalent. For this part of the results, the researchers divided it into several points, namely the points that include teachers' perception and the points that include teachers' readiness.

\section{Research Results related to Teachers' Perception}

Some Matters That Change in the Learning Process

The researchers explored teachers through open-ended questions about what changed in the learning process during the COVID-19 pandemic. Various responses and stories of teachers were certainly directly felt by the teachers during teaching. Teachers felt a fairly drastic change during this time was related to learning processes and patterns. Before the COVID-19 pandemic, teachers were accustomed to learning offline or known as face-to-face. However, when pandemics occurred, faceto-face learning was gradually reduced and replaced with online learning methods. Sometimes teachers also applied home visits or visited directly to students' homes one by one to provide lessons. Teachers certainly did this to implement a blended learning system that was a must in the COVID19 pandemic.

Teachers also felt significant changes to the use of technology media and learning applications such as google classroom, zoom, and so on to support the online learning process. Thus, teachers and students with parents must be literate in technology and information to get quality learning. In order for quality learning using online, teachers were also required to change the way they teach, including teachers applying practice learning patterns to learners with students' daily lives, such as cleaning their beds, helping mothers wash dishes and so on.

Teachers' duties increased during the current pandemic times. Teachers became more extra in providing materials than before. They must be more creative, interactive, and able to motivate students to be spirit to go to school. It is because in the COVID-19 pandemic times, the economy of some parents decreased, and students were required to get involved in work. In addition, from the students' side, much had changed related to communication and the closeness of teachers and students became reduced. Students were difficult to direct, control, and the characters and attitudes were not polite, more courageous to argue, and did negative deeds. When learning took place, many students who played games and discipline also became a fairly drastic change. It is quite sad indeed; the changes made it difficult for teachers to evaluate assessments to students.

The researchers viewed that the changes that occurred in the learning process during the COVID-19 pandemic times became a necessity. All elements of life had changed, without exception the world of education. Whether we like it or not, this change that occurred must be experienced together. According to Okwita (2015), people's social life is always experiencing change. Changes in 
people's lives are a natural social phenomenon. It is also supported by research from Prasetyawati (2013), who states that all parties must support changes that occur in the learning process, and changes that occur are something normal.

\section{Strategies to Deal with Changes in Learning}

Teachers' strategies for learning change were quite diverse. Based on the teachers' answers, the average learning process was carried out using blended learning strategies or offline and online, doing home visits or terms given by guling program teachers, learning games, and even some who used storytelling strategies. In Online strategies, teachers were required to be able to understand, enriched knowledge of technology. It was related to using technology for learning such as WhatsApp, zoom, google classroom, PowerPoint, e-learning. Learning content became a surefire strategy that teachers did. Then, in the guling (Traveling Teacher) program, teachers had determined the right schedules to visit students. Sometimes, teachers also applied a learning system while playing traditional and modern games.

The learning strategies formulated by these teachers are certainly in line with the opinion of Pujiasih (2020), Sudrajat (2020), and Hamdani and Priatna (2020). They mapped out learning models in online learning, google classroom, cooperative learning, quizizz games, meaningful works and products, and online assessments to create learning that appeals to students. Based on the definition, the strategy that the teachers formulated ran smoothly when the teachers cooperated between parents and the environment in the learning process.

In addition, teachers also changed the model and learning time given; for example, students must fill out a list of attendance until midnight on the same day with the purpose of the activity carried out became assessment material. In addition, so that the strategy carried out was valuable and quality, the teachers, also made changes in the delivery of learning materials with a simple language and create modules, lastly, for assessing the needs of learners using AKPD (Assessment of Student Needs). The Assessment of Student Needs was shared through e-learning applications, WhatsApp groups, google Forms. Then, from the results of this assessment, the teachers compiled RPL. The following process was carried out assessment and implementation of strategies that have been formulated.

\section{The Obstacles in Learning During a Pandemic}

In learning, during the COVID-19 pandemic, many obstacles occurred. Based on the results of an open questionnaire, the researchers saw that two parties experienced these obstacles, namely teachers (teachers) and learners. The obstacles experienced by teachers and students were the limitations of technological equipment for the learning process, such as android phones, laptops, and tablets. Thus, the learning that could run well could not be fulfilled due to the lack of technological equipment. Teachers who had technological equipment also experienced obstacles, namely the ability to operate and use. It was also still minimal, so when learning took place was not maximal in its use. In addition, internet networks that did not support the teaching and learning process were also challenging for teachers, especially teachers in the countryside. Certainly, this kind of deficiency was unfortunate for the world of Indonesian education.

As seen once during the COVID-19 pandemic, Indonesian education is not ready. Thus, teachers taught as they were with various limitations, one of which was an internet network that was not qualified. The obstacles that occurred were not only related to technology but from the psychological side of the teacher. Indonesian teachers were quite stressed facing learning situations during pandemics, even bored with the situation that changes. The researchers viewed, most teachers in Indonesia were not ready for different learning situations. It also affected learners who were not motivated and lethargic to learn. Especially in this pandemic, the poverty rate was increasing and affecting the economy of parents of students. Parents whose economy was declining due to the termination of employment also affected the education of the students. In contrast, all 
learning requires technological tools, internet quotas, and various other devices that can all be done if parents' economy is fine. It was a problem that occurred from two sides of the learning element.

\section{Effective Learning Model}

Based on the study results, the model that teachers often used in the learning process was a problem-based learning model and inquiry. Both learning models could make learners overcome problems by searching and finding the best solution when learning occurred. The teachers often used this model when the situation was normal. Also, this model brought together teachers and learners directly. However, keep in mind, when researchers explored directly to the teachers, the teachers realized that an effective learning model was an ideal learning model applied in a variety of situations and conditions, including conditions during the COVID-19 pandemic. The effective learning model is a model that meets the requirements, including learning based on skills and abilities, needs, manners and character, discussion and problem solving, utilization of information technology media, methods of playing while learning by paying attention to the level of development stages of learners. Thus, if the model is applied will be able to create maximum learning outcomes.

\section{Curriculum Implementation Model That Is Feasible to Apply during a Pandemic}

When the COVID-19 pandemic, teachers were still faced with dilemmas to create the right curriculum implementation model, thus making the researchers formulate a targeted implementation model. Based on the research results, researchers summarized four right implementation models to be applied: integrated, collaborative, thematic, and real-life learning. Integrated is a curriculum implementation model that emphasizes one unit between subjects. For example, when children are given IPA lessons about the universe, students will also learn about Islam and can even be directed to IPS lessons. Furthermore, this curriculum model requires collaboration and cooperation between teachers, students, and parents, so there were no more learning stories directed only to teachers and teacher responsibilities. Thematics is the third implementation model that supports the integrated model process, thus creating harmonization in various subjects when given to students. The last is real-life learning, a model of implementation of the learning curriculum through activities that are real in the lives of learners. So that when it runs, it will be embedded in students' minds.

\section{Research Results related to Teacher Readiness}

Teacher Readiness for Curriculum Implementation

In this section, the researchers explored the teachers' readiness from indicators that demonstrate curriculum implementation and adaptive learning (see table 1).

As stated in table 1, the percentage of teachers' readiness for each indicator presented has reached 50\% more. It means that in the field itself, although there were still many difficulties and limitations that existed, teachers were fundamentally ready to face adaptive learning. They were practically experienced in conducting competency and curriculum analysis, determining learning goals, determining their materials and strategies, determining the media and duration of learning independently, and being experienced in making their assessment instruments. On those basics, it can be said that they were ready and became the best predictors in doing adaptive learning. 
Table 1. Teacher Readiness in Curriculum Implementation and Adaptive Learning

\begin{tabular}{|c|c|c|c|}
\hline No & Indicators & Frequency & Percentage (\%) \\
\hline \multirow[t]{3}{*}{1} & $\begin{array}{l}\text { Do guidebooks to implement curriculum and adaptive learning } \\
\text { require? }\end{array}$ & & \\
\hline & YES & 326 & 99.7 \\
\hline & NO & 1 & .3 \\
\hline \multirow[t]{3}{*}{2} & $\begin{array}{l}\text { Have the teachers ever analyzed and mapped the competencies in } \\
\text { the curriculum before carrying out learning? }\end{array}$ & & \\
\hline & YES & 229 & 70.2 \\
\hline & NO & 98 & 29.8 \\
\hline \multirow[t]{3}{*}{3} & Have the teachers ever formulated a learning goal? & & \\
\hline & YES & 298 & 91.1 \\
\hline & NO & 29 & 8.9 \\
\hline \multirow[t]{3}{*}{4} & Have the teachers ever specified the material to be used? & & \\
\hline & YES & 303 & 92.6 \\
\hline & NO & 24 & 7.4 \\
\hline \multirow[t]{3}{*}{5} & Have the teachers ever defined a theme in learning? & & \\
\hline & YES & 266 & 81.3 \\
\hline & NO & 61 & 18.7 \\
\hline \multirow[t]{3}{*}{6} & The teachers determine the learning strategies themselves & & \\
\hline & YES & 280 & 85.6 \\
\hline & NO & 47 & 14.4 \\
\hline \multirow[t]{3}{*}{7} & The teachers determine effective media in learning themselves & & \\
\hline & YES & 294 & 89.9 \\
\hline & NO & 33 & 10.1 \\
\hline \multirow[t]{2}{*}{8} & $\begin{array}{l}\text { The teachers determine the duration of time for each activity } \\
\text { themselves }\end{array}$ & & \\
\hline & YES & 247 & 75.5 \\
\hline \multirow[t]{3}{*}{9} & $\begin{array}{l}\text { NO } \\
\text { The teachers conduct the assessment in the learning process }\end{array}$ & 80 & 24.5 \\
\hline & YES & 286 & 87.4 \\
\hline & NO & 41 & 12.6 \\
\hline
\end{tabular}

Note. The total number of respondents was 326.

\section{Basic References Used to Perform Adaptive Learning}

In table 1 described earlier, most teachers had practised adaptive learning during this pandemic. Optimization of these activities was determined from personal aspects and from various basic references they made as references or guides in carrying out the practice. These references included the curriculum that was the source of the implementation of activities, RPL and syllabus, which were specific manifestations of the curriculum, related government rules, sources of teaching materials such as books, journals, magazines, and other media, the results of their questionnaires that they usually shared personally to their students, analysis of relatedness to current topics, and contextualization of learning that could occur outside the learning plan.

\section{Types of Adaptive Learning Activities that Can Be Used}

The research results show that teachers in Indonesia mostly applied these learning activities with observation, questioning, and recitation. The observation that the teacher carried out was direct observations of the object of learning studies to learners. The questioning was the stage of Q\&A between teachers and students, students and teachers, between students, students and their environment, whether to their parents later or playmates related to learning. Furthermore, recitation was the process of repeating to memorize the material to understand and continue to remember the lessons given.

\section{Forms of Effecttic Assessment for Adaptive Learning}

To implement adaptive learning, certainly, an assessment is needed that is relevant to exist learning. The results show four assessment models that could be used to conduct adaptive learning: an assessment based on paper and pencil tests, student performance assessments, learning product assessments, and authentic assessments. Each of these assessment forms had advantages and 
procedures that were different, so in practice, teachers could use only one form or even combine various forms at a time. The use of such forms of assessment depends on the material and the learning objectives to be achieved.

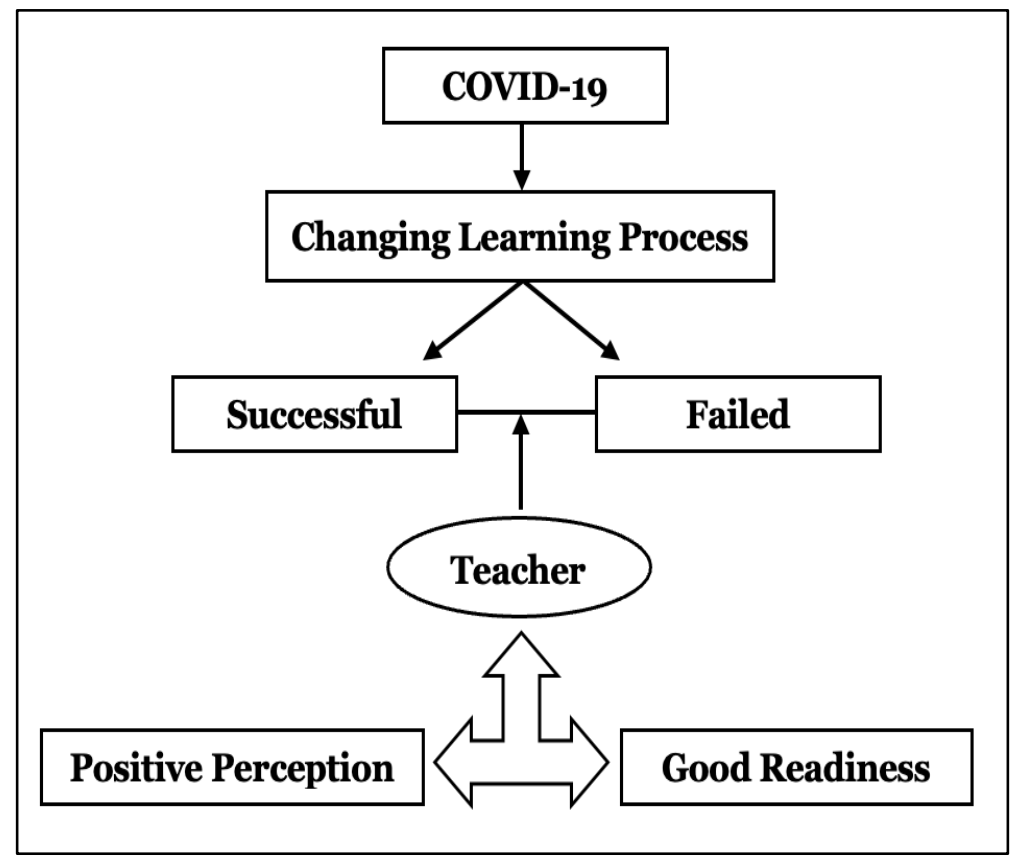

Figure 2. Research Framework

The results of previous research provide a comprehensive picture of what kind of learning conditions occurred due to the covid-19 pandemic. It must be recognized that the changes that occurred in the beginning, made the dynamics of learning optimization became hampered. However, when viewed from the perception conveyed by teachers, they could learn many new things, which improved their competence and preparedness. It is certainly supported by several studies that prove that stressful changes in individuals can be a positive means for them to grow better and gain valuable experience when the same situation occurs again at some point (Lee et al., 2019; Rahardi \& Dartanto, 2021; Wiziack \& dos Santos, 2021).

The changes that occurred during this pandemic required teachers to create adaptive learning systems. Adaptive learning became a learning model based on contextuality in the field, the needs analysis of the learners, and the variety of situations that made learning flexible but still able to achieve the best targets. Adaptive learning was indispensable in the situations like this pandemic. With this learning model, every teacher could continue to conduct the learning process even under challenging situations. The study results of respondents' answers show that almost all teachers had practised the learning model in this study. It is seen from the maximum percentage amount in table 1 and answers that relate to the references they used in implementing the learning process.

Many factors certainly determine adaptive learning that is expected to be done by teachers. As was the case in this study, positive perception and attitude and teacher readiness (Figure 2) become essential factors that can qualitatively strengthen adaptive learning practices. These positive perceptions and attitudes will be the initial assets for teachers to survive and deal with the changes that occur, while readiness is needed as their reinforcement to continue developing and finding the meaning of learning. Ultimately, the researchers believe that what happened during this pandemic was an exercise for teachers to discover the nature of learning and education itself. The changes that occurred led to positive changes in all aspects of learning. 


\section{CONCLUSION}

The study concluded that teachers' perceptions were closely related to their readiness practically to carry out adaptive learning in pandemic times. Teachers felt that the change in the learning process in the pandemic was a very complex situation, so they had to do many things to keep the learning going optimally. Basically, because of the pandemic, new learning emerged that could be referred to as adaptive learning. Adaptive learning required teachers to be ready and flexible to carry out learning in any situation, even in the most difficult situations. The study results also point out that teachers had practised adaptive learning habits in their activities, so this became another form of optimism for optimal learning in this pandemic period.

The researchers believe that the results of this study are very implicative and could be the basis for other research that our current learning can recover and still achieve the expected outcomes. In the future, more objective research is needed to identify factors that can make learning more optimal by being packaged through an experimental approach. It is also necessary to differentiate between levels of education; it can be at the elementary, junior high, and high school levels. The researchers also hope that to facilitate this adaptive learning can be done; it is necessary to create a guidebook that facilitates and becomes a guide for teachers to carry out adaptive learning.

\section{ACKNOWLEDGEMENT}

The researchers express their gratitude to the Center of Curriculum and Books, Ministry of Education, Culture, Research, and Technology, that has provided research and development grants (Risbang) to conduct this research.

\section{REFERENCES}

Aldridge, M. D., \& McQuagge, E. (2021). "Finding my own way": The lived experience of undergraduate nursing students learning psychomotor skills during COVID-19. Teaching and Learning in Nursing, 1-5. https://doi.org/10.1016/j.teln.2021.07.002

Amri, A., Ramdani, Z., Warsihna, J., \& Tae, L. F. (2021). Tungku tigo sajarangan, tali tigo sapilin: A strategy towards world class university based on local wisdom perspective. AL-ISHLAH: Jurnal Pendidikan, 13(1), 31-40. https://doi.org/10.35445/alishlah.v13i1.386

Fauzi, I., \& Sastra Khusuma, I. H. (2020). Teachers' elementary school in online learning of COVID19 pandemic conditions. Jurnal Iqra': Kajian Ilmu Pendidikan, 5(1), 58-70. https://doi.org/10.25217/ji.v5i1.914

Fitrah, M., \& Ruslan, R. (2020). Eksplorasi sistem pelaksanaan evaluasi pembelajaran di sekolah pada masa pandemi covid-19 di Bima. Jurnal Basicedu, 5(1), 178-187. https://doi.org/10.31004/basicedu.v5i1.639

Fitriani, Y. (2020). Analisa pemanfaatan learning management system (LMS) sebagai media pembelajaran online selama pandemi covid-19. JISICOM (Journal of Information System, Informatics and Computing), 4(2), 1-8. http://journal.stmikjayakarta.ac.id/index.php/jisicomTelp.+62-21-3905050,

Hamdani, RA., \& Priatna, A. (2020). Efektifitas implementasi pembelajaran daring (full online) dimasa pandemi covid- 19 pada jenjang sekolah dasar di kabupaten Subang. Didaktik : Jurnal Ilmiah PGSD STKIP Subang, 6(1), 1-9. https://doi.org/10.36989/didaktik.v6i1.120

Kanya, N., Fathoni, A. B., \& Ramdani, Z. (2021). Managerial strategies of institution toward student's emotional dynamic during COVID-19: A preliminary finding from thematic content analysis $\begin{array}{llll}\text { perspectives. Psychology and } & \text { Education, 2849-2855. }\end{array}$ www.psychologyandeducation.net

Lee, K., Choi, H., \& Cho, Y. H. (2019). Becoming a competent self: A developmental process of adult distance learning. Internet and Higher Education, 41, 25-33. https://doi.org/10.1016/j.iheduc.2018.12.001 
Mansyur, Abd. R. (2020). Dampak COVID-19 terhadap dinamika pembelajaran di Indonesia. Education and Learning Journal ,1(2), 113-123. http://jurnal.fai@umi.ac.id

Marliani, R., Nasrudin, E., Rahmawati, R., \& Ramdani, Z. (2020). Regulasi emosi, stres, dan kesejahteraan Psikologis : Studi pada ibu work from home dalam menghadapi pandemi COVID19. In Karya Tulis Ilmiah LP2M UIN SGD Bandung. http://digilib.uinsgd.ac.id/30722/

Mouratidis, K., \& Papagiannakis, A. (2021). COVID-19, internet, and mobility: The rise of telework, telehealth, e-learning, and e-shopping. Sustainable Cities and Society, 74, 103182. https://doi.org/10.1016/j.scs.2021.103182

Okwita, A. (2015). Perubahan kehidupan sosial ekonomi masyarakat pasca bencana gempa 30 september 2009 nagari gunung padang alai kecamatan v koto tomir kabupaten Padang Pariaman. Jurnal Dimensi, 53(9).

Prakoso, B. H., Ramdani, Z., \& Rahmah, B. (2021). Self-introspection in teaching students with virtual learning in COVID-19 pandemic: A qualitative finding. Proceedings of the International Conference on Educational Assessment and Policy (ICEAP 2O2O), 12-15.

Prasetyawati, Indah Purnama, T. (2013). Pendidikan kesehatan sekolah dasar sebagai proses perubahaan perilaku siswa. Jurnal Pendidikan Jasmani Indonesia, 9(2), 141-147.

Pujiasih, E. (2020). Membangun generasi emas dengan variasi pembelajaran online di masa Pandemi Covid-19. Ideguru: Jurnal Karya Ilmiah Guru, 5(1), 42-48. https://doi.org/10.51169/ideguru.v5i1.136

Rahardi, F., \& Dartanto, T. (2021). Growth mindset, delayed gratification, and learning outcome: evidence from a field survey of least-advantaged private schools in Depok-Indonesia. Heliyon, 7(4). https://doi.org/10.1016/j.heliyon.2021.eo6681

Ramdani, Z. (2017). Forgiving is not only forgetting (phenomenological study on forgiveness in individu who experiences a friendship conflict. IJASOS- International E-Journal of Advances in Social Sciences. https://doi.org/10.18769/ijasos.366853

Ramdani, Z., Amri, A., Warsihna, J., Garnasih, T. R., \& Juarsa, E. (2021). Perilaku manajemen keuangan karyawan selama pandemi covid-19: Sebuah studi awal. E-QIEN: Jurnal Ekonomi Dan Bisnis, 8(1), 170-179.

Ramdani, Z., Amrullah, S., \& Tae, L. F. (2019). Pentingnya kolaborasi dalam menciptakan sistem pendidikan yang berkualitas. MEDIAPSI, 5(1), 40-48.

Reed, M. S., Fraser, E. D. G., \& Dougill, A. J. (2006). An adaptive learning process for developing and applying sustainability indicators with local communities. Ecological Economics, 59(4), 406-418. https://doi.org/10.1016/j.ecolecon.2005.11.008

Restauri, N., \& Sheridan, A. D. (2020). Burnout and posttraumatic stress disorder in the coronavirus disease 2019 (COVID-19) pandemic: Intersection, impact, and interventions. Journal of the American College of Radiology, 17(7), 921-926. https://doi.org/10.1016/j.jacr.2020.05.021

Sulasmono, B. S., \& Dwikurnaningsih, Y. (2012). Pengembangan model pembelajaran adaptif, kooperatif, aktif dan reflektif (Pakar). Satya Widya, $28(1), 93$. https://doi.org/10.24246/j.sw.2012.v28.i1.p93-110

Sudrajat, J. (2020). Kompetensi guru di masa pandemi covid-19. Jurnal Riset Ekonomi Dan Bisnis, 13(1), 100-110. http://journals.usm.ac.id/index.php/jreb

Tae, L. F., Ramdani, Z., \& Shidiq, G. A. (2019). Analisis tematik faktor-faktor yang mempengaruhi keberhasilan siswa dalam pembelajaran sains. Indonesian Journal of Educational Assessment, 2(1), 79-102. http://ijeajournal.kemdikbud.go.id

Tahrir, T., Ramdani, Z., \& Natanael, Y. (2021). Character strenghts, islamic religiousness, and ethnic identity: A preliminary study on santri experiencing boredom learning. Psikoislamika: Jurnal Psikologi Dan Psikologi Islam, 18(1), 188-200. https://doi.org/10.1886o/psi.v18i1.11347 
Vandewaetere, M., Desmet, P., \& Clarebout, G. (2011). The contribution of learner characteristics in the development of computer-based adaptive learning environments. Computers in Human Behavior, 27(1), 118-130. https://doi.org/10.1016/j.chb.2010.07.038

Warsihna, J., \& Ramdani, Z. (2020). Signifikansi Kahoot: Interaksi manusia dan mesin dalam proses pembelajaran. Kwangsan: Jurnal Teknologi Pendidikan, o8(02), 154-167.

Whillans, A., Perlow, L., \& Turek, A. (2021). Experimenting during the shift to virtual team work: Learnings from how teams adapted their activities during the COVID-19 pandemic. Information and Organization, 31(1). https://doi.org/10.1016/j.infoandorg.2021.100343

Wiziack, J. C., \& dos Santos, V. M. P. D. (2021). Evaluating an integrated cognitive competencies model to enhance teachers' application of technology in large-scale educational contexts. Heliyon, 7(1). https://doi.org/10.1016/j.heliyon.2021.e05928

Yuan, Y.-P., Wei-Han Tan, G., Ooi, K.-B., \& Lim, W.-L. (2021). Can COVID-19 pandemic influence experience response in mobile learning? Telematics and Informatics, 64, 101676. https://doi.org/10.1016/j.tele.2021.101676

Zvolensky, M. J., Garey, L., Rogers, A. H., Schmidt, N. B., Vujanovic, A. A., Storch, E. A., Buckner, J. D., Paulus, D. J., Alfano, C., Smits, J. A. J., \& O'Cleirigh, C. (2020). Psychological, addictive, and health behavior implications of the COVID-19 pandemic. Behaviour Research and Therapy, 134(August), 103715. https://doi.org/10.1016/j.brat.2020.103715 